\title{
Taking as giving, appropriation as access: transfers of land development rights and China's recent experiments
}

\author{
TING $\mathrm{XU}^{*}$
}

Queen's University Belfast

WEI GONG**

London School of Economics

\begin{abstract}
$\underline{\text { Abstract }}$
Economic development at both the domestic and global levels is associated with increasing tensions which are inextricably linked to the meaning and allocation of property rights, which has a great impact on appropriation of resources and may lead to different paths of development. 'Taking' - the appropriation of private land for public needs - is a typical example that exbibits those tensions, posing a challenge to the conventional conception of property as individualistic and exclusive rights of possession, use and disposition and to the associated neoliberal model of development. Should the individual landowner be left to bear the cost of a regulatory intervention which endures to the wider benefit of the whole community? How can the tensions between private ownership and public regulation be mitigated? If we take the liberal concept of property, then private property seems to be in constant conflict with public interests and wider social concerns. Meanwhile, community, situating between the state and the individuals, and community's relationship to development rights have not provoked enough discussion. The paper explores the different ways land development rights might be seen both in Western, essentially common law, systems and in China, especially now and in view of two case studies. An empirical example in Wugang, China, reveals the importance of integrating the 'community lens' proposed by Roger Cotterrell into studies of the transfer of land development rights. Reading through the community lens, taking could be giving and appropriation could also be access. This approach provides a new perspective to re-evaluate the relationship between legal appropriation and development.
\end{abstract}

\section{Introduction}

$\mathrm{E}$ conomic development at both the domestic and global levels is associated with increasing tensions including those between the urban and the rural, efficiency and equity, private ownership and public regulation, the rights of individuals and of communities, and the North and the South. Those tensions are inextricably linked to the meaning and allocation of property rights, which has a great impact on appropriation of resources and may lead to different paths of development. 'Taking' - the appropriation of private land for public needs - is a typical example that exhibits those tensions, posing a

* Lecturer in Law t.xu@qub.ac.uk. The authors would like to thank Jean Allain, Gordon Anthony, Alison Clarke, Roger Cotterrell, Amanda Perry-Kessaris, John Morison, and Tim Murphy for deep and insightful comments.

** Research Officer w.gong2@1se.ac.uk. 
challenge to the conventional conception of property as individualistic and exclusive rights of possession, use and disposition and to the associated neoliberal model of development. ${ }^{1}$

This article seeks to answer two closely related questions: should the individual landowner be left to bear the cost of a regulatory intervention which endures to the wider benefit of the whole community? How can the tensions between private ownership and public regulation be mitigated?

The article starts with a discussion of the challenges posed by economic development to the liberal/neoliberal conception of property. It then reviews the evolution of land development rights in Western, essentially common law systems, and in China, especially now and in view of two case studies.

Land development rights can be defined as 'the right to change the use of a parcel of land from one yielding a lower return [agricultural use] to a use yielding a higher return [urban residential, commercial, or industrial use], with consequent increase in its value'. ${ }^{2}$ While recognising the importance of development rights in takings of land, practices in the US and UK have been largely confined to the liberal framework. By contrast, two case studies of China's recent developments in the transfer of land development rights ${ }^{3}$ provide an alternative way of re-evaluating the two questions raised above. Empirical examples focus on the practices in Wugang and Chongqing in China, two pilot cities chosen by the Chinese government to experiment with the transfer of land development rights. Albeit with many limits, transfers of development rights in the these two cities have opened up possibilities of integrating local people, who are often excluded and sometimes exploited in land development, into the process of appropriation and allocation of land resources. Compared to US practice, Wugang's experiments highlight the importance of integrating the community lens proposed by Roger Cotterrell ${ }^{4}$ into studies of the transfer of land development rights.

As an old social science concept, there are many interpretations of what community is or should be. Roger Cotterrell sees 'community' as networks of social relations held together by a variety of bonds (e.g. a convergence of economic interests, shared custom, common values) and based on mutual interpersonal trust. ${ }^{5}$ Drawing on Weber's four types of social action (traditional, affectual, instrumentally rational and value-rational), ${ }^{6}$ Cotterrell's 'networks of relations of community' encompass four ideal types of community: instrumental community, traditional community, community of belief and affective community. Cotterrell stresses the relations between law and community (rather

1 This model of development is often characterised by outright privatisation.

2 D Monson and A Monson, 'Development and Practice of British Planning Law' (1949-1950) 44 Illinois Law Review 779, 785.

3 The transfer of development rights is not limited to transfers of land rights, but is widely discussed in the context of climate change, the greenhouse effect and air pollution. The Kyoto Protocol in 1997, for example, has established a framework of trading in quotas or emission credits for carbon emission. Similar examples include tradable fishing quotas and transferable air-pollution permits. See e.g. C M Rose, 'Expanding the Choices for the Global Commons: Comparing Newfangled Tradable Allowance Schemes to Old-Fashioned Common Property Regimes' (1999) 10 Duke Environmental Law and Policy Forum 45.

4 See e.g. R Cotterrell, Law, Culture and Society: Legal Ideas in the Mirror of Social Theory (Ashgate 2006) 65-78; 'Community as a Legal Concept? Some Uses of a Law-and-Community Approach in Legal Theory', in R Cotterrell, Living Law: Studies in Legal and Society Theory (Ashgate 2008) 17-28.

5 Cotterrell, Law, Culture and Society (n 4).

6 M Weber, Economy and Society: An Outline of Interpretive Sociology, E Fischoff (trans) (University of California Press 1978) 23-26. 
than an abstract 'society' ${ }^{7}$ and the roles of law in expressing and strengthening the trust that binds different actors in relations of community. Different relations of community pose different regulatory problems. ${ }^{8}$ Therefore successful regulation often depends on whether law could act as a communal resource, strengthening trust and co-operation within networks of relations of community. ${ }^{9}$ This method contrasts the liberal/neoliberal approach to disembed law from wider social life and provides 'a sociological analysis of the role of law in economic life'. ${ }^{10}$ Furthermore, such a communal approach to appropriation and development goes beyond many 'boundaries' entrenched in property law ${ }^{11}$ including the public-private divide. This approach may help to resolve C B Macpherson's famous tensions between property as a right to exclude and property as a right of access. ${ }^{12}$ Reading through the community lens, taking could be giving and appropriation could also be access.

\section{Liberal property regime: a recipe for economic development?}

The most-cited classical liberal concept of private property is William Blackstone's definition of property as 'the sole and despotic dominion which one man claims and exercises over the external things of the world, in total exclusion of the right of any other individual in the universe'. ${ }^{3}$ Such a perception of property as 'exclusive rights of possession, use, and disposition' has been strengthened by the economic analysis of law, which argues that property rights must be 'strong and clear' in order to preserve a wellfunctioning market and thereby promote economic growth. ${ }^{14}$ This proposition remains influential in theoretical analysis ${ }^{15}$ and has profound appeal to many development projects promoted by the World Bank and International Monetary Fund. ${ }^{16}$ This conception of property points to a single development path, which is expected to be followed by all developing countries. However, many development paths have challenged the neoliberal assertion that property rights must be strong and clear. China's economic growth, for

7 In this approach, 'society is disintegrating into many different networks of social relations in and beyond nation states'. Cotterell, Law, Culture and Society (n 4) 65.

8 For discussion of the strengths and weaknesses of each type of community and its relation to law, see e.g. Cotterrell, Law, Culture and Society (n 4) 73-5, 154-58; Cotterrell, 'Community as a Legal Concept?' (n 4) 22-25.

9 See A Perry-Kessaris, Global Business, Local Law: The Indian Legal System as a Communal Resource in Foreign Investment Relations (Ashgate 2008); A Perry-Kessaris, 'Reading the Story of Law and Embeddedness through a Community Lens: A Polanyi-Meets-Cotterrell Economic Sociology of Law?’ (2011) 62(3) Northern Ireland Legal Quarterly 401. See also T Xu, 'Global Legal Transplants through the Lens of Community: Lessons for and from Chinese Property Law' in A Perry-Kessaris (ed), Socio-Legal Approaches to International Economic Law: Text, Context and Subtext (Routledge, 2012) 167-80.

10 See R Swedberg, 'The Case for an Economic Sociology of Law' (2003) 32 Theory and Society 1, 1. See also R Cotterrell, 'Rethinking "Embeddedness": Law, Economy, Community' (2013) 40(1) Journal of Law and Society $49,49$.

11 For more discussion, see e.g. M Heller, ‘The Boundaries of Private Property’ (1999) 108 Yale Law Journal 1163.

12 C B Macpherson, 'Capitalism and the Changing Concept of Property' in E Kamenka and R S Neale (eds), Feudalism, Capitalism and Beyond (Edward Arnold 1975) 105-24.

13 W Blackstone, Commentaries on the Laws of England, vol I: Of the Rights of Persons (Clarendon Press 1766) 2.

14 Ronald Coase is most cited for this proposition: see e.g. 'The Problem of Social Cost' (1960) 3 Journal of Law and Economics 1.

15 See e.g. R Epstein, Takings: Private Property and the Power of Eminent Domain. (Harvard University Press 1985); H De Soto, The Mystery of Capital: Why Capitalism Triumphs in the West and Fails Everywhere Else (Black Swan 2001); T Bethell, The Noblest Triumph: Property and Prosperity through the Ages (St Martin's Press 1998).

16 For criticism on this approach, see e.g. D Kennedy, 'Some Caution about Property Rights as a Recipe for Economic Development' (2011) 1(1) Accounting, Economics, and Law 1 <www.bepress.com/ael/ vol11/iss1/3>; R Dyal-Chand, 'Exporting the Ownership Society: A Case Study on the Economic Impact of Property Rights' (2007) 39 Rutgers Law Journal 59; M Heller, The Gridlock Economy: How Too Much Ownership Wrecks Markets, Stops Innovation, and Costs Lives (Basic Books 2010). 
example, provides a counter-example that China's growth rate is high, while private property rights remain weak and vague. Furthermore, the liberal conception of property enshrines 'efficiency' but largely ignores 'equity' in the use and allocation of property rights. In doing so, it overlooks the question of who wins and loses in the process of appropriation and development and the necessity of looking for alternative property regimes and paths of development. Seen from the liberal perspective, any legislative restriction on one of the 'exclusive rights' is, prima facie, a taking, ${ }^{17}$ including most forms of land acquisition for public needs such as zoning restrictions and eminent domain (also known as condemnation). ${ }^{18}$ Indeed, taking often involves 'the conflict between private and public interests in the use of a piece of land'. ${ }^{19}$ From the liberal point of view, such conflicts are irresolvable because appropriation of land for public needs, usually accompanied by government regulation, restricts appropriation of land resources by the individuals. A boundary between the public and the private is entrenched and is hard to cross.

Nevertheless, taking seems unavoidable in economic development in which land needs to be assembled for development projects. As the result of takings often involves economic loss of private parties, ${ }^{20}$ compensation is one of the core issues in taking. For example, in the US, the private parties' entitlement to compensation depends on whether the taking is eminent domain, which is the process through which a government condemns a resource for a public use and compensation to private parties is required. Indeed, the idea that eminent domain should be coupled with compensation at 'fair market value' has been entrenched in the US Constitution. ${ }^{21}$ If a taking is for 'public use' and if the owner is paid fair market value, the taking is justified. Yet, 'by implicitly understanding all property to be fungible' and 'fully interchangeable with money', the liberal conception of property acquiesces in the broad power of eminent domain. ${ }^{22}$ So, the liberal concept of property leads itself to a paradox that it ironically justifies takings and leaves the eminent domain power uncontrolled. ${ }^{23}$ Furthermore, eminent domain is embedded in a particular constitutional framework with which the US saddled itself in a pre-development era and may not be an effective mechanism to deal with new taking issues in recent economic development.

Indeed, it is often neglected that 'the ownership of property, in and of itself, is of little value to an individual. Instead, it is the owner's ability to put that property to a particular use that creates value in property'. ${ }^{24}$ So, how should profits generated from the increase in land value due to development and change in use be distributed? Should ownership of land include a right to the development value (usually in the form of capital gain) that results from urban growth? Should the grant of compensation consider the fact that the owner may have developed a personal connection to the $\operatorname{land}^{25}$ (this may also involve communal interest to that land)?

17 M J Radin, Reinterpreting Property (Chicago University Press 1993) 122.

18 Eminent domain refers to 'the power of any government body to compel a private owner to sell at a price fixed by a court. When government pays for property it is free of the constraint of the taking issue': see R H Platt, Land Use and Society: Geography, Law, and Public Policy (Island Press 2004) 278.

19 D Krueckeberg, 'The Difficult Character of Property: To Whom do Things Belong?' (1995) 61 Journal of the American Planning Association 301, 304.

20 J L Sax, ‘Takings, Private Property and Public Rights’ (1971) 81(2) Yale Law Journal 149, pp.150-151.

21 US Constitution: 'Nor shall private property be taken for public use, without just compensation' (the last clause of the Fifth amendment).

22 Radin (n 17) 136, 156.

23 Ibid 135-37.

24 J Stinson, 'Transferring Development Rights: Purpose, Problems, and Prospects in New York' (1996) 17(1) Pace Law Review 319, 322.

25 Radin (n 17) 142. 


\section{Taking as giving: the evolution and transfer of land development rights}

Neoliberalists assume that the market does the whole job of allocation of resources. However, in contemporary society the state is 'doing more and more of the work of allocation' 26 in the form of regulation through which public rights are being increasingly inserted into private property. This has paved the way for the evolution and recognition of land development rights. For example, in the UK, 27 takings of private land for public use (in particular, the acquisition of land for development) are in the form of 'compulsory purchase', ${ }^{28}$ which refers to 'the compulsory purchase of any land under powers conferred by or under any statute'. ${ }^{29}$ Like the US, 'right to compensation' is one of the core issues in compulsory purchase and the compensation should be fair and include market value. ${ }^{30}$ The question is whether the market value should include 'any betterment' which refers to 'any increase in the market value of the retained land attributable to the nature of, or the carrying out of, the relevant project'. ${ }^{31}$

International treatises and documents also stress the importance of regulation on land development and reasonable constraints on private property. For example, the pivotal property provision of the European Convention on Human Rights 1950 proclaims, in Protocol 1, Article 1, that:

Every natural or legal person is entitled to the peaceful enjoyment of his possessions. No one shall be deprived of his possessions except in the public interest and subject to the conditions provided for by law and by the general principles of international law.

The preceding provisions shall not, however, in any way impair the right of a State to enforce such laws as it deems necessary to control the use of property in accordance with the general interest or to secure the payment of taxes or other contributions or penalties'.

The land policy of the United Nations (UN), first officially articulated at the UN Conference on Human Settlements (Habitat I) in 1976, 32 is along the same lines. The Preamble of Agenda Item 10(d) of the Conference Report says:

Land . . . cannot be treated as an ordinary asset, controlled by individuals and subject to the pressures and inefficiencies of the market. Private land ownership is also a principal instrument of accumulation and concentration of wealth and therefore contributes to social injustice; if unchecked, it may become a major obstacle in the planning and implementation of development schemes. The provision of decent dwellings and healthy conditions for the people can only be

26 Macpherson (n 12) 117.

27 This article concentrates on the law of England. However, some aspects of the law on compulsory purchase apply throughout United Kingdom.

28 See e.g. T Allen, 'Controls over the Use and Abuse of Eminent Domain in England: A Comparative View' in R P Malloy (ed), Private Property, Community Development, and Eminent Domain (Ashgate 2008) 75-100. The origin of compulsory purchase lies in the Town and Country Planning Act 1947. Other pieces of major legislation include the Land Compensation Act 1961, the Compulsory Purchase Act (1965), the Town and Country Planning Act 1990, Planning and Compulsory Purchase Act (2004).

29 Law Commission, 'Towards a Compulsory Purchase Code: (1) Compensation, An Overview' (Law Com Consultation Paper No165, 2004) 4.

30 Ibid 6. However, in some cases, market value does not necessarily mean fairness. For example, individuals bought at the top of the property market a few years ago, but the market value fell and the individuals are being compensated for the market value of the property at today's prices. These situations are being condemned to negative equity. Thanks to Professor Gordon Anthony for raising this point.

31 Law Commission (n 29) 8.

32 Held in Vancouver, Canada, 31 May-11 June 1976. 
achieved if land is used in the interests of society as a whole. Public control of land use is therefore indispensable...33

Diverse measures ${ }^{34}$ of public control of land (in particular of agricultural land on the periphery of urban areas) use are listed in Recommendation D2 of the report. Measures (ii) and (v) recognise land development rights. Measure (ii) specifies 'acquisition of development rights' along with 'the creation of land reserves and land banks'. Measure (v) emphasises 'co-ordination between orderly urban development and the promotion and location of new developments, preserving agricultural land'.35 Furthermore, 'Recommendation D.3 recapturing plus value' provides that 'the rise in land values resulting from change in use of land ... must be subject to appropriate recapture by public body (the community)'. Yet it is still difficult to answer the question: should the individual landowner be left to bear the cost of a regulatory intervention which endures to the wider benefit of the whole community? If we take the liberal concept of property, then private property seems to be in constant conflict with public interests and wider social concerns. Community, situating between the state and the individuals, and community's relationship to development rights, have not provoked enough discussion.

The evolution of the transfer of land development rights, a process emerging from zoning and city planning in the US since the 1960s, provides a vehicle not only for compensating betterment in the taking of private land for development but also an alternative for traditional ways of taking, such as eminent domain. The transfer of development rights is 'trading a development restriction on one property for the right to develop on another'. ${ }^{36}$ The nature of the transfer of development rights is 'regulatory tools designed to facilitate land use planning, ${ }^{37}$ setting a 'regulatory cap'38 of land resources, usually for purposes of nature conservation and environmental protection. What are being transferred in the process are quotas or credits of land for future development. 39 Furthermore, the transfer of land development rights in the US could be interpreted as requiring that the state recognises ownership of land development rights by private owners, and the state must purchase the development rights from private owners or allow development rights to be traded freely in market as commodities. In this way, the transfer of land development rights could mitigate the harsh consequences associated with eminent domain and constitute a form of just compensation.

The most frequently cited of the many examples of the transfer of land development rights are the New York plan and the Chicago plan. ${ }^{40}$ New York city began to experiment with the transfer of land development rights in 1961. The city restricted the use of the property on which historic landmarks are located and the owner may transfer his or her development rights to another property he or she owns in the receiving area. ${ }^{41}$ In the New York plan, the land development right is vested in the same owner but can be transferred

33 <http://habitat.igc.org/vancouver/vp-d.htm>.

34 Such measures include zoning and land-use planning, purchase, compensated expropriation and fiscal controls such as taxation.

35 <http://habitat.igc.org/vancouver/vp-d.htm>.

36 Stinson (n 24) 330.

37 Ibid 324.

38 C Rose, 'The Several Futures of Property' (1998) 83 Minnesota Law Review 129, 164.

39 See e.g. V Renard, 'Property Rights and the 'Transfer of Development Rights': Questions of Efficiency and Equity' (2007) 78 (1) TPR 41; A D Ellerman, 'A Note on Tradeable Permits' (2005) 31 Environmental and Resources Economics 123.

40 M D Strugar, 'Transferable Development Rights: Robbing Peter to Pay Paul?' (1985) 62(4) University of Detroit Law Review 633, 634.

41 Ibid. 


\section{Preservation zone}

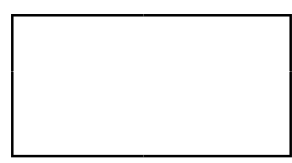

Sending area

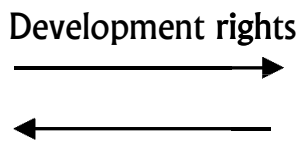

$\$ \$ \$ \$ \$ \$$
Growth zone

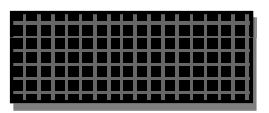

Receiving area

Figure 1. Transfers of development rights ${ }^{42}$

to different locations. The Chicago plan resembles the New York plan, but also departs from it: while restricting the use of the development of the plot of the land where historic landmarks are located, the city of Chicago allowed the unused development rights of that land to be transferred elsewhere as compensation to the owner. ${ }^{43}$ Chicago city also set up a city-run 'development rights bank' through which land development rights were bought and sold. In cases where an owner did not wish to participate directly in the transfer of land development rights, the city had to purchase or condemn that preserved site and compensated the owner with land development rights in the form of cash from the profits generated from the bank. ${ }^{44}$

However, the transfer of land development rights is more than a form of compensation but, in fact, constitutes another form of taking, that is, the taking of development rights rather than ownership. At the same time, the transfer of land development rights can also be a form of giving. For instance, in the US examples, the development rights were taken away from the landowner in order to preserve the historic sites, but in the meantime value was given to both the local community (the continued pleasure/amenity of having a beautiful building preserved as part of their neighbourhood) and to wider communities (a building of artistic, architectural and historic importance is preserved as part of the national or world heritage). Furthermore, two other kinds of giving also happened in the transfers of development rights. First, land owners whose development rights had been taken were given in exchange the right to develop other land elsewhere (or money in lieu, supplied by landowners elsewhere who chose to buy the development rights from him/her). Secondly, the local community in the 'receiving area' was given local benefits provided by the enabled development in the receiving area and the wider community was given the benefits of a planned environment. ${ }^{45}$

In order for the giving to happen, the practice of transfers needs to integrate the 'communal dimension', that is, reconciling individualistic and exclusive ownership with communal interests and participation. This communal dimension is crucial for a successful transfer programme. Voluntary participation and public confidence in the value of transferred land development rights are particularly important. ${ }^{46}$ For example, in order to avoid the situation that a biased regulation burdens one participant (whether the property owners or property developers) in a transfer programme, a comprehensive zoning plan needs to be drafted so that 'reciprocity of advantage' and 'consensus' can be achieved in order to 'benefit the entire community' and to 'maximise the efficient use of community resource and to minimise the deleterious consequence of development. ${ }^{47}$ This calls for

42 Platt (n 18) 272.

43 Ibid 635

44 Ibid.

45 Thanks to Professor Alison Clarke for raising this point.

46 Stinson (n 24) 346.

47 Stinson (n 24) 349-51. 
various participation and support from both the sending and receiving areas in order to strike the balance between overprotection of individual rights and state coercion. ${ }^{48}$ The next section explores this issue further through two case studies of the transfer of land development rights in China.

\section{The transfer of land development rights in China}

\section{LEGAL FRAMEWORK FOR LAND ACQUISITION AND THE URBAN-RURAL DIVIDE}

It may be useful to contextualise our central concerns by looking briefly at the Chinese legal system. Law-making in China is guided by a so-called principle that 'broad legislation is always better than detailed'. National law only provides general principles and needs to be complemented by various kinds of regulations for implementation. As a result, there exists a complex hierarchy of law-making power and legislative organs. Specifically, according to the Legislation Law of the People's Republic of China 2000, the National People's Congress and Standing Committee exercise state legislative power (Article 7). And only national laws may be enacted in respect of matters relating to 'acquisition of non-state assets' (Article 8(6)). The State Council enacts administrative regulations in accordance with the Constitution and national law in order to implement national law (Article 56). Various ministries and commissions under the State Council also exercise regulatory power and make administrative rules in accordance with national law, administrative regulations, and decisions and orders of the State Council in order to implement administrative regulations (Article 71). Local People's Congresses and Standing Committees make local decrees and local governments make local rules within their authorities (Articles 68, 71). In theory, the Constitution has the highest authority, followed by administrative regulations, which have higher authority than local decrees and administrative or local rules (Article 79). In reality, appropriation of land resources is often decided by different forms of regulation. Moreover, land acquisition is often empowered by local rules, which often contradict national law, leading to disputes and conflicts between local government and the people.

China's land system is underpinned by the urban-rural divide, an entrenched feature of the Maoist era (1949-1976). This divide generated and continues to generate inequality between rural and urban development in many respects, including social security, infrastructure investment, education and health care. Post-Mao, and especially in the postDeng period (1992-present), legal and administrative distinctions between urban and rural become blurred. ${ }^{49}$ Yet the land system remains an obstacle for bridging the urban-rural gap. Although equal protection of state, collective and private property is one of the important principles of Property Law 2007(Article 4), two kinds of unequal ownership exist in the contemporary Chinese land system. ${ }^{50}$ Urban land is owned by the state, which can grant and allocate land-use rights, and local governments therefore can transfer these land-use rights. By contrast, while in law rural land is collectively owned, what constitutes 'the collectives' is ill-defined. The de facto owners are often local governmental authorities such

48 It is quite likely that a receiving area is too distant from the sending (preserving) area, and what is being protected in the sending area is hardly to be realised: see ibid 349.

49 Decollectivisation in 1978 loosened the control over the rural population on leaving the countryside, and urbanisation and rural industrialisation make the urban-rural boundaries blurred. The blurred boundaries are demonstrated in e.g. rural-urban migration and the rapid urban expansion.

50 A tri-ownership system, including state ownership, collective ownership and private ownership, has evolved and persisted. Property Law 2007 provides equal protection for public property and private property for the first time since 1949, but there is much debate over whether private property should be given the same status as public property. Furthermore, in contrast to the official, and indeed legal, support for unitary and exclusive property rights, the reality of the property regime has seen fragmentation of property rights in which de facto owners are multiple. 
as administrative villages and the township-level government. Farmers may not in law dispose of their land freely and are vulnerable to compulsory land acquisition by the state. ${ }^{51}$ In the process of urbanisation and industrialisation, rural land is generating significant profits; however, local governments, officials and property developers are enjoying these profits, while farmers are often excluded and sometimes exploited. Land acquisition is a typical example.

Land acquisition is the only way for farmers' land-use rights to enter into the market. Both the Chinese Constitution ${ }^{52}$ and the Land Administration Law $^{53}$ specify that the state, in the public interest, ${ }^{54}$ may lawfully acquire land owned by collectives. This sets the mechanism for compulsory land acquisition. The Land Administration Law states that compensation shall be given in accordance with the original use of the acquired land, ${ }^{55}$ and the compensation is through a package that includes compensation for the land, resettlement subsidies and compensation for fixtures to, and young or green crops on, the acquired land. Article 42 of Property Law 2007 expands the scope of compensation to 'the premiums for social security of the farmers' in order to guarantee their normal lives and safeguard their lawful rights and interests. However, the compensation is still not specified to be paid at full market prices, not to mention the recognition of development rights. Indeed, without taking account of either the market value of the land and the land development rights, local governments can acquire rural land from farmers at a low price (e.g. RMB30,000-50,000 RMB/mu, ${ }^{56}$ equivalent to US $\$ 321-535 /$ hectare) and sell it to property developers at a high price (e.g. millions of $\mathrm{RMB} / m u$ ). A great profit thus could be made because of the huge gap between these two different prices.

\section{CHINA'S LAND POLICY}

China needs to feed 1.3 billion people but arable land only constituted 13 per cent of the total land in 1996 and this figure decreased to 11.8 per cent in 2009. ${ }^{57}$ Preserving 1.8 billion $m u$ of arable land in order to ensure the country's food supply is a national policy. Guided by this policy, the Land Administration Law was revised in 1998 in order to exert strict control over the use of arable land. The central government has also formulated a master plan for land utilisation, which classifies the purposes of land use into agricultural use, construction use and unused. Land development must be in accord with the master plan, ${ }^{58}$ and property developers need to apply for 'agricultural use land conversion quotas' (that is, the quotas that land for agricultural use can be converted to construction uses) set out in the master and annual plans. ${ }^{59}$

51 For more discussion, see T Xu, 'The End of the Urban-Rural Divide? Emerging Quasi Commons in Rural China’ (2010) 96(4) Archiv für Rechts und Sozialphilosophie (the Archives for Philosophy of Law and Social Philosophy) 557.

52 Constitution 2004, Article 10(3).

53 Land Administration Law 2004, Article 2(4)

54 In China, the definition of public interest is at the discretion of the government in particular local governments. Many lavish commercial and industrial projects have been built in the name of public interest. For a recent review of the notion of public interest in a global context, see J Morison and G Anthony, 'The Place of Public Interest' in G Anthony et al (eds), Values in Global Administrative Law (Hart Publishing 2011) 215-38.

55 Land Administration Law 2004, Article 47

561 hectare $=15 \mathrm{mu}$.

57 < http://data.worldbank.org/indicator/AG.LND.ARBL.ZS/countries> accessed 15 January 2013.

58 Article 23 of the Regulations on the Implementation of the Land Administration Law 1998, promulgated by the State Council on 27 December 1998; implemented on 1 January 1999.

59 See Article 19 of the Regulations on the Implementation of the Land Administration Law 1998, promulgated by the State Council on 27 December 1998; implemented on 1 January 1999. 
Yet 'agricultural use land conversion quotas' set out in the land-use plans cannot always meet the need of land for development projects in the context of rapid economic growth and urbanisation. Furthermore, by the end of 2004, rural-to-urban migration left 4 million mu of land idle, populated only by low-density and abandoned farmers' residential plots. The State Council responded with a policy on 'consolidation of rural construction land' in 2004, encouraging farmers to consolidate their abandoned residential plots or to move into highdensity residential blocks. ${ }^{60}$ Then the land of their old residential plots could be converted to arable land, which means that construction land in rural areas may decrease subsequently, creating quotas for construction land in urban areas. A balance between the increase in urban construction land and the decrease in rural construction land could be achieved.

\section{THE TRANSFER OF LAND DEVELOPMENT RIGHTS IN WUGANG 61}

Wugang city (county level) is located in Henan province, central China. The city has 190 administrative villages (xingzheng cun) and 834 natural villages (ziran cun $)^{62}$ with a population of approximately 320,000 . The city houses one of China's biggest iron and steel companies. A lake that runs through the city with beautiful mountains surrounding it has made Wugang a popular tourist destination in recent years.

The experiment with the transfer of land development rights in Wugang is made possible by a larger rural reform project - 'merging villages into planned neighbourhoods', colloquially referred to the measure of 'linking up the increase in urban construction land and the decrease in rural construction land' discussed above. In 2005, the Ministry of Land and Resources issued a proposal to standardise this measure and began the experiment with 'merging villages into planned neighbourhoods' in five provinces including Shandong, Jiangsu, Hubei, Sichuan and Tianjin in 2006. ${ }^{63}$ The experiment has expanded on a nationwide scale since 2009. As a pilot city for this experiment in Henan province, Wugang has begun to relocate farmers to condensed residential places such as newly built flats in residential blocks in the rural area. New planned neighbourhoods have been formed. Farmers have also been offered houses and flats cheaper than the market price and subsidies and loans without interest for house purchase. Land previously used for rural residence, unused land, and land abandoned by villagers who have moved to the cities as rural migrant workers has been converted into farmland. The conversion created extra quotas (land development rights) for construction land, which could be transferred to and used in developing cities and towns. Overall, the amount of construction land has not increased and the amount of arable land has not decreased.

The city government aims to merge 834 villages into four towns and 17 planned neighbourhoods. There are nine planned neighbourhoods under construction to be finished by 2015 . So far $27,000 m u$ (1800 hectare) of land has been made available for urban construction. ${ }^{64} \mathrm{New}$ neighbourhoods have been constructed according to their local advantages in industry, trade or service. In those neighbourhoods close to industrial areas, farmers could get new jobs in the factories. For example, Shangcao community at Tieshan

60 'Decision on Land Administration Reform', No 28 (2004), State Council.

61 The empirical material is gathered from both authors' fieldwork in Wugang, China in August 2011. We interviewed local officials and farmers who participated in the transfer of land development rights.

62 'Natural villages' emphasises villages 'in the sense of what is local and long-standing', while 'administrative villages' refers to 'the collective' or 'sub-government institutions'. See S Feuchtwang, 'What is Village?' in E B Vermeer et al (eds), Cooperative and Collective in China's Rural Development: Between State and Private Interests (M E Sharpe 1998) 47.

63 'The measure of linking up the increase in urban construction land and the decrease in rural construction land' (Ministry of Land and Resources 2005)

64 Data collected from interviews with local officials. 
town is close to a shoe factory which employs more than 6000 workers. These neighbourhoods also provide many opportunities for farmers to engage in trade or service. For example, Zhangzhuang community of Yinji town is a tourist destination located in a beautiful area of reservoir basin. Farmers often live in newly built two-level houses. They live on the ground floor and the first floor is used as bed and breakfast accommodation. Yinji town is also a production centre for traditional Chinese medicine, providing many job opportunities for local farmers. Farmers have formed new networks of social relations based on common commercial interests and professional specialisations, that is, 'instrumental (economic) community'.

\section{Preservation zone (agricultural land)}

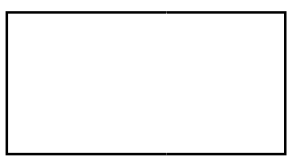

Sending area

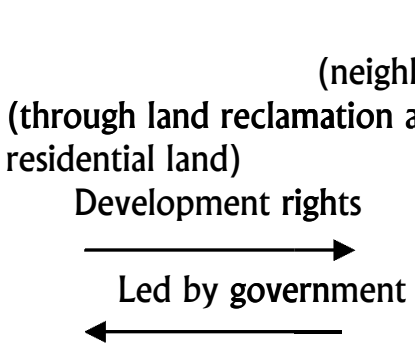

$¥ ¥ ¥ ¥ ¥$

\section{Growth zone}

(neighbourhoods/towns)

\section{)}

Figure 2: The transfer of land development rights in Wugang, China ${ }^{65}$

\section{THE TRANSFER OF LAND DEVELOPMENT RIGHTS IN CHONGQING: LAND TICKETS TRANSFER 66}

Chongqing is a major city in southwest China and one of the four directly controlled municipalities by the central government. It is the largest municipality located in inland China, comprising 19 districts and 21 counties. ${ }^{67}$ As one of the fastest urbanising cities in China, by the end of 2010, Chongqing's urban resident population had reached 15.29 million which constituted 53 per cent of the total 33.03 million population. ${ }^{68}$

Chongqing was chosen by the National Development and Reform Commission as an 'experimental zone for comprehensive integration of urban and rural development' in June 2007. As part of the experiment, in 2008, Chongqing set up a Rural Land Exchange Centre, a division of Chongqing Bureau of Land and Resources, in which land tickets (dipiao, land quotas or credits), equivalent to land development rights, can be traded. The processes usually include: rural land in remote areas (usually abandoned land by farmers who have migrated to cities or new land made available through 'merging villages into planned neighbourhoods') is reclaimed and converted into new farmland; the increase of farmland and the subsequent decrease of rural construction land generate new quotas for urban land that could be used for construction purposes; the Rural Land Exchange Centre combines separate quotas generated by consolidation of small pieces of land (e.g. $0.3 \mathrm{mu}$ of construction land generated from one small piece of land) into a large bundle (e.g. hundreds of $m u$ of construction land), which constitutes a land ticket; land tickets are then sold to various kinds of property investors and developers including the Urban Development

65 This model is based on Platt's (n 18) Figure 1.

66 Empirical material is gathered from the second-named author's fieldwork in Chongqing, China in March 2012. The author interviewed local officials especially those in the Rural Land Exchange Centre and farmers.

67 Chongqing Survey Yearbook 2011 (China Statistics Press 2011) 4.

68 Ibid 3. 
Investment Companies, ${ }^{69}$ state-owned enterprises, private enterprises or property developers through auctions at the Rural Land Exchange Centre; finally, the Rural Land Exchange Centre distributes the income from selling the land tickets to farmers whose residential plots have been converted into farmland for making new quotas for construction land. As farmers (strictly speaking, the households) only hold land-use rights and village committees 'own' rural land ownership, farmers are entitled to around 85 per cent of the income and the village committee is entitled to around 15 per cent of the income. Distribution of income among farmers is according to each household's contribution to generating one land ticket. However, acquiring land quotas does not mean gaining real land. Companies which have successfully acquired land quotas only have entitlements to using land for urban development. They still need to go through the processes of bid and auction held by another division of the Bureau of Land and Resources in order to buy land use rights for construction purposes. Developers must also ensure that redevelopment of the land is in accordance with city land planning. Furthermore, there is no second-level market for trading land development rights.

(Agricultural land)

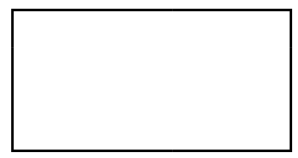

Sending area

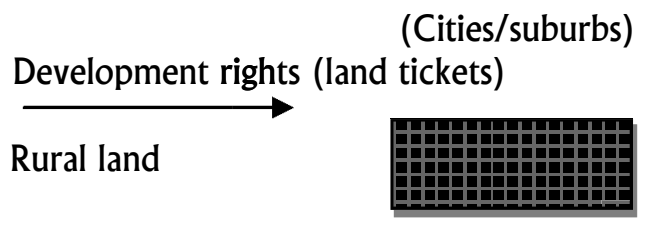

Exchange centre

$¥ ¥ ¥ ¥ ¥$

\section{Receiving area}

Figure 3: The transfer of land development rights in Chongqing 70

Eleven auctions held by May 2010 at the Exchange Centre have raised land quotas amounting to 1200 hectares $(18,000 \mathrm{mu})$ of land, equivalent to 1.9 billion yuan. Official policy makes it clear that profits generated in the trade of land tickets shall be reinvested in agricultural and rural development as well as spent as compensation to villages and farmers for housing demolition and as subsidies for building new houses. The exchange of land tickets has enabled profits generated from the process of urbanisation and the expansion of the urban land market to trickle down into the hands of farmers. It also created possibilities for a unified urban and rural land market.

\section{WugAng AND CHONGQING EXPERIMENTS COMPARED}

In Wugang, the measure of linking up the increase in urban construction land and the decrease in rural construction land can only be applied within the administrative jurisdiction at the country level. To put it another way, land development rights (quotas) generated for construction use can only be used in the same area where rural land has been consolidated. So, the sending area and receiving area are within the same locality or at least close enough. The disadvantage of this restriction may be that the compensation standard is often set very low, because the land development rights are usually transferred to newly built neighbourhoods or towns close to the sending area. Although subsidies and loans are provided for farmers, the compensation does not amount to market values of the acquired land. Yet, since the receiving area is close to the sending area, the rural area has gained

69 The Urban Development Investment Companies act as land development agents for local government.

70 This model is based on Platt's (n 18) Figure 1 
opportunities for development, while arable land could still be preserved, both constitute important kinds of giving. The Wugang experiment also stresses the importance of community in the process of development. Although the construction of planned neighbourhoods is mainly led by the government and driven by economic motivation, it has considered 'non-economic' components of economic networks ${ }^{71}$ that farmers could keep emotional or sentimental attachment to the rural land, while enjoying developmental opportunities as members of the newly formed community.

In Chongqing, administrative boundaries may be crossed through the exchange of land tickets. Land tickets raised in the remote rural areas are traded together with land tickets raised in the suburban areas of Chongqing with the same price through auctions and bids. Therefore one of the advantages of this experiment is that farmers in the remote area could get a relatively high level of compensation. However, as the receiving area is too distant from the sending area, real development is concentrated on cities and their peripheries, which may enlarge the gap between the rural and the urban areas. Furthermore, most successful bidders of land tickets are the Urban Development Investment Companies, commercial property developers and manufacturing enterprises. Before acquiring land tickets, they usually have a considerable amount of land already reserved in hand but not yet within city planning and thus not ready for development. Getting land tickets 'legitimises' the use of their already reserved land but may create monopolies of land. Moreover, these bidders have often cultivated 'under-the-table' relationships with the local government and among themselves, which help them to lower the prices in the bidding processes. Unlike the transfer of land development rights in the US, which may mitigate the harsh consequences of takings of land ownership, the transfer of land development rights in Chongqing actually creates more quotas for 'takings' of rural land ownership. Problems are also centred on: how to allocate land transfer income; how to avoid excessive involvement of local governments; and how to make sure that farmers participate in the transfer of development rights voluntarily?

\section{Conclusion: taking as giving, appropriation as access through the community lens}

What constitutes community? Is it only limited to the sense of geographical entities? What is the relationship between community and law? We have briefly outlined Cotterrell's 'lawin-community' approach in the introduction, and this approach is not without criticism. Simon Roberts, for example, argues that:

[Cotterrell] proposes that state law should reach out to co-ordinate and facilitate the operation of plural legal orders at the level of 'community'. Some of these accounts tell a story of the covert expansion of state power, and of increased opportunities for coercion and manipulation. ${ }^{72}$

However, Cotterrell does not intend to prescribe, but offers a method to observe and explain the penetration of state power into the private sphere in the form of regulation, which now seems an irreversible trend. Furthermore, it is often easy to label Cotterrell's approach as an 'ideal-type' Western theory. However, the approach is in nature a methodology, and is not characteristically Western. ${ }^{73}$ In fact, the community lens proposed by Cotterrell is a useful method that could be applied to the Chinese context. Take the Wugang experiment, for example: community is never a static entity. Farmers keep moving out of the villages and forming new kinds of community, transforming old networks of social relations and creating new ones. In the transfer of land development rights in

71 Cotterrell (n 10), 56.

72 S Roberts, 'Domesticating the Sociology of Law' (2008) 71(1) Modern Law Review 132, 142.

73 See Cotterrell, 'Community as a Legal Concept?’ (n 4) 17-18. 
Wugang, the sending and receiving areas are dynamic networks of social relations rather than static geographical entities. Some effective aspects of the regulation strengthen and facilitate trust, co-operation, and reciprocity of benefits among different actors of community (for example, farmers, local governments and private developers). Furthermore, although there are always clashes and overlaps between different networks of social relations, one network of community is often dominated by one type of social relations. For example, the newly formed community in Wugang is dominated by instrumental social relations that engage with market activities and share the benefits of urban development. Nevertheless, this does not mean that the old social relations have disappeared or regulation should not take the old social relations into account. In Wugang, while being located to new neighbourhoods, farmers still keep emotional attachment to the farmland and tradition and custom are not entirely abandoned, due in part to the arrangement that the receiving area is close to the sending area.

The community lens also sheds light on rethinking the relationship of legal appropriation and development. As Radin argues, a system of property holding needs to be justified by community participation. ${ }^{74}$ Krueckeberg also points out that 'rights to personal use of property are fundamental to individual and social well-being; rights to profit from property, in contrast, have always been subject to reasonable constraints for the benefit of the entire community and the society'. ${ }^{75}$ Property is social relations, encompassing entitlements and obligations. Property law governs 'the contours of social relations' ${ }^{76}$ The community lens helps to look at diverse communal relations existing between individual autonomy and state control, offering opportunities to explore plural property regimes. Stressing the community lens is important to avoid the limits of public/private dualism and to reconcile the tensions between private property and public regulation.

Taking, appropriation of private land for public use, often points to a right of exclusion. However, in our evaluation of Wugang's experiment with the transfer of land development rights, the community lens helps to show the possibility of appropriation as right of access. Although farmers' land development rights were taken for purposes of preserving arable land, new networks of social relations were formed based on farmers' common economic interests and professional specialisations through which they were able to access alterative development opportunities ('participatory development') in newly formed neighbourhoods. In this context, appropriation, being read through the community lens, is not just about the right to exclude but also the right to access, and taking could also be giving. Stressing the community lens provides a useful vehicle to rethink not only the practice of the transfer of land development rights but also the relationship between legal appropriation and development. Law will often face the dilemma that law steals or is stolen by development, unless law recognises the importance of networks of social relations. This is not simply recognising that the capital gain by urban development should return - at least the large part of it - to the community. More importantly, law needs to engage with different networks of social relations, strengthen trust and co-operation among different actors in relation of community. Finally, as the networks of social relations transcends the boundaries of the nation state, cutting across the local and the globe, the community lens would also be useful for analysing law and development issues on a global scale. And this will be the subject of another paper.

74 Radin (n 17) 164.

75 Krueckeberg (n 19) 307.

76 J W Singer, Entitlement: The Paradoxes of Property (Yale University Press) 61. 